\title{
RELIABILITY STUDY OF SPECTRAL ACCELERATION DESIGNS AGAINST EARTHQUAKES IN BENGKULU CITY, INDONESIA
}

\author{
Lindung Zalbuin Mase ${ }^{1 *}$ \\ ${ }^{1}$ Department of Civil Engineering, Faculty of Engineering, University of Bengkulu, \\ WR. Supratman Rd, Kandang Limun, Muara Bangkahulu, Bengkulu 38371, Indonesia
}

(Received: August 2017 / Revised: January 2018 / Accepted: April 2018)

\begin{abstract}
This paper presents a reliability study of spectral acceleration designs against earthquakes in Bengkulu City. Seismic Hazard Analysis of 1,968 events is performed to define the controlling earthquake event. Furthermore, the controlling earthquake is used as the scale factor to generate five input motions for one-dimensional seismic response analysis. The spectral accelerations resulting from the analysis are then compared to the updated spectral acceleration design. The results show that spectral acceleration designs are still able to cover the spectral acceleration of seismic response analysis. However, for the short period, the spectral acceleration of seismic response analysis exceeds the designed spectral acceleration. This is a matter of concern, since most of the building natural period in Bengkulu City is still categorized as short. In general, this study brings awareness to the design aspect considering earthquakes in Bengkulu City in order to reduce the possible impact on structures in the future.
\end{abstract}

Keywords: Earthquakes; Seismic hazard analysis; Seismic response analysis; Spectral acceleration

\section{INTRODUCTION}

It is known that earthquakes are a natural hazard which could trigger massive damage to a region such as Indonesia (Kanata et al., 2014; Sukanta et al., 2015). In 2000, a $7.90 \mathrm{M}_{\mathrm{w}}$ earthquake occurred in Bengkulu Province, Indonesia. It resulted in destructive damage, including collapsed buildings, fatalities, and injuries. The earthquake also triggered other catastrophic hazards, such as landslides and liquefactions in mountainous and coastal areas in Bengkulu. Seven years later, another big earthquake with a magnitude of $8.6 \mathrm{M}_{\mathrm{w}}$ hit the area (Mase, 2017a). This earthquake also resulted in structural damage and other geotechnical phenomena, such as ground failure and liquefaction. During both events, Bengkulu City suffered more serious impact than other cities and regencies in Bengkulu Province, due to the fact that the released energy of the earthquakes in 2000 and 2007 was very large (Mase, 2017a). Learning from these earthquake events, this earthquake study of Bengkulu Province is focused on Bengkulu City. Large earthquake events have not only happened in Bengkulu Province, but also in many other provinces in Indonesia, such as Nangroe Aceh Darussalam in 2004, North Sumatra in 2005, and West Sumatra in 2009. Those earthquakes also triggered massive structural damage, which revealed that the seismic design code in Indonesia needs to be evaluated. Considering these earthquake events, the Indonesian Government revised the previous seismic design code (SNI 03-1726-2002) to a new one (SNI 03-1726-2012). The updated

\footnotetext{
*Corresponding author's email: Imase@unib.ac.id, Tel. +62-73-621170, Fax. +62-73-622105

Permalink/DOI: https://doi.org/10.14716/ijtech.v9i5.621
} 
seismic design code is now becoming the reference for local engineers in Indonesia for construction design (Mase \& Somantri, 2016), and should be considered as design practice for buildings all over Indonesia.

In this study, a seismic response analysis due to earthquakes is presented. The study aims to check the reliability of the updated seismic design code (SNI 03-1726-2012) with regard to earthquakes in Bengkulu. The ground motion is propagated from the surface of engineering bedrock through the soil layer. At the ground surface, it is further transferred to the spectral acceleration curves, which are compared to the updated seismic design code. In addition, the amplification factor between the propagated ground motion and the ground motion analyzed at the ground surface is also presented. In general, the study is expected to provide better understanding of seismic ground response analysis in Bengkulu City, as well as to provide suggestions to local engineers in consideration of spectral acceleration design for construction design in Bengkulu City.

\section{STUDY AREA AND GENERAL GEOLOGICAL CONDITIONS}

The study area is located along the coastal area of Bengkulu City (Figure 1), where during the 2000 and 2007 earthquakes large-scale destruction took place. In the study, standard penetration test (SPT) and spectral analysis of surface wave (SASW) test were conducted, and information from the tests interpreted to establish the geological conditions of the investigated area. In general, the sub-soil in the area was dominated by sandy soils. Loose sand classified as SP was found at a depth range of 0 to $1.5 \mathrm{~m}$, and 7.5-9 m, with $\left(\mathrm{N}_{1}\right)_{60}$ of 5-6 blows/ft and FC (fines content) of 4-7\%. Medium sand classified as SM existed at a depth range of 1.5 to $22.5 \mathrm{~m}$, with $\left(\mathrm{N}_{1}\right)_{60}$ of $15-25$ blows/ft and $\mathrm{FC}$ of 10 to $18 \%$. At a depth range of 22.5 to $30 \mathrm{~m}$, dense sand layers classified as SC and SM were found. In terms of soil resistance, $\left(\mathrm{N}_{1}\right)_{60}$ on these layers ranged between $25-35$ blows/ft, with FC of 16-22\%. According to the National Earthquake Hazard Reduction Program, or NEHRP (1998), in general site classification of the study area is categorized as stiff soil (site class type D), with $\mathrm{V}_{\mathrm{S} 30}$ (average of $\mathrm{V}_{\mathrm{S}}$ up to $30 \mathrm{~m}$ deep) of 298 to $302 \mathrm{~m} / \mathrm{s}$.

\section{METHOD OF ANALYSIS}

\subsection{Seismic Hazard Parameter}

Peak ground acceleration (PGA) prediction is very important in earthquake risk analysis. This parameter is normally estimated by the attenuation model, which corresponds to the earthquake source mechanism. In Bengkulu, there are two major earthquake sources, which have triggered many intensive earthquake events: shallow crustal sources, which include active tectonic fault earthquakes and stable continental region earthquakes; and the subduction zone, which includes intraplate and interplate earthquake events.

In this study, several attenuation models (Table 1), which are designed to estimate the peak ground acceleration at the bedrock of these earthquake mechanisms, are employed to determine the PGA parameter. In Table 1, for the shallow crustal earthquake mechanism occurring in the active tectonic fault region, Next Generation Attenuation (NGA) models are used, including those of Abrahamson et al. (2014), Boore et al. (2014), Campbell and Bozorgnia (2014) and Chiou and Youngs (2014). For earthquakes occurring in the stable continental region, the attenuation models used are those of Dahle et al. (1995), Hwang and Huo (1997), Toro (2002) and Pezeshk et al. (2011). The Atkinson and Boore (2003), Kataoka et al. (2006), Shoushtari et al. (2016) and Idini et al. (2017) models are used to predict the PGA for earthquakes under a subduction mechanism. These attenuation models for the earthquake source mechanism consider earthquake uncertainty, such as magnitude, source distance, and site effect, which vary due to the geotechnical and geological aspects. 

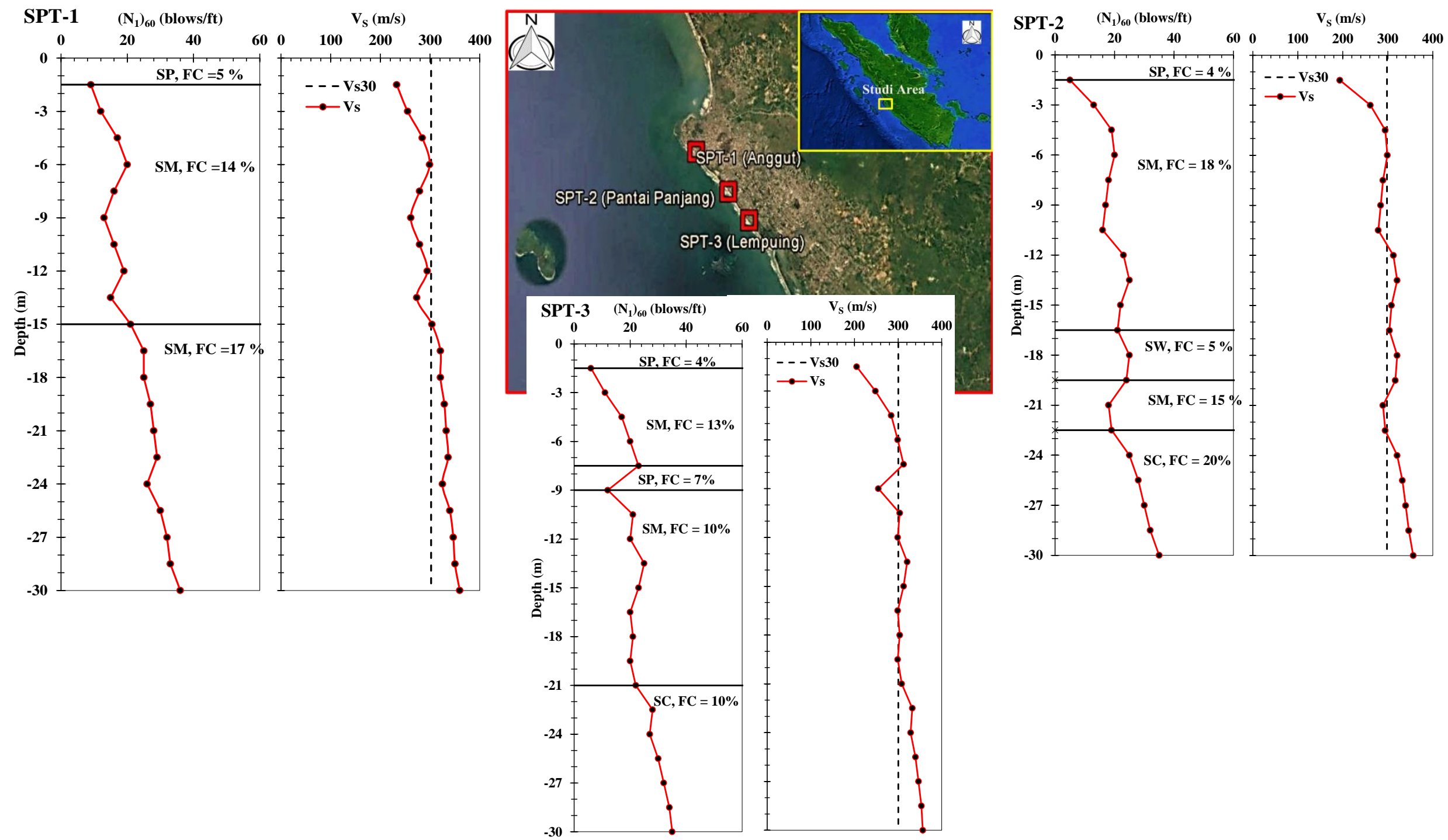

Figure 1 Study area and site investigation results 


\subsection{Deterministic Seismic Hazard Analysis}

Seismic Hazard Analysis is normally performed to predict the risk level of earthquake impact, which includes probabilistic seismic hazard analysis (PSHA) and deterministic seismic hazard analysis (DSHA) (Reiter, 1990). PSHA is a statistical method used to predict a representative earthquake, considering its recurrence in a region (Kinasih et al., 2014), whereas DSHA is a simple deterministic method which determines the most credible earthquake or the controlling earthquake. In DSHA, the most credible earthquake is predicted based on the serious impact on the study area (Mase \& Somatri, 2016).

Table 1 Attenuation models used in the study

\begin{tabular}{lll}
\hline \multicolumn{1}{c}{ Active Tectonic Region } & \multicolumn{1}{c}{ Stable Continental Region } & \multicolumn{1}{c}{ Subduction Zone } \\
\hline Abrahamson et al. (2014) & Dahle et al. (1995) & Atkinson \& Boore (2003) \\
Boore et al. (2014) & Hwang \& Huo (1997) & Kataoka et al. (2006) \\
Campbell \& Bozorgnia (2014) & Toro (2002) & Shoushtari et al. (2016) \\
Chiou \& Youngs (2014) & Pezeshk et al. (2011) & Idini et al. (2017) \\
\hline
\end{tabular}

The impact on the site is defined by the Modified Mercalli Intensity (MMI) scale proposed by Wood and Neuman (1931). In this study, a total of 1,968 earthquake events in Bengkulu Province zone are analysed by the DSHA method. The data are collected from Mase's (2010) study and the National Agency for Meteorology, Climatology and Geophysics, or BMKG (2017), website. These earthquakes occurred in 2000-2016. During this period, seismic activity in Bengkulu Province increased significantly. Among the 1,968 events, the significant earthquakes occurring each year are selected. These earthquakes are called the representative earthquakes, and are plotted in Figure 2.

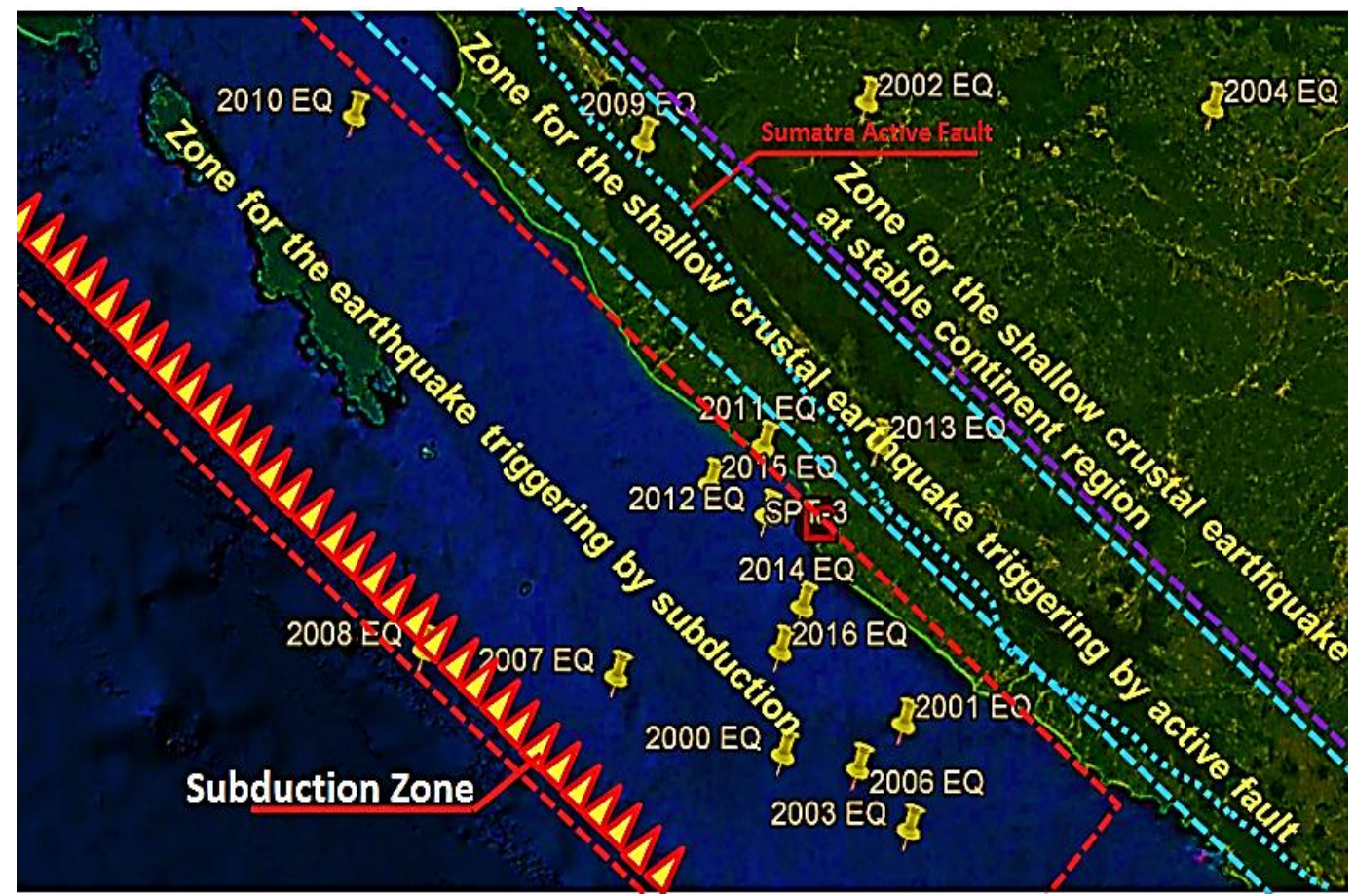

Figure 2 Representative earthquakes each year (modified from Google Earth, 2017)

In Figure 2, the earthquake zones corresponding to the source mechanism are depicted; i.e. the subduction zone, active fault zone, and stable continental zone. From this zonation, estimation of the earthquake source can be determined. Table 2 compiles the representative earthquakes from the period 2000 to 2016 and presents the source mechanism and type of earthquake. 
Among the representative earthquakes, the 2009 and 2013 events are categorised as shallow crustal earthquakes, being active tectonic region type. Both earthquakes occurred due to activity in the Sumatra Fault (locally, the Semangko Fault). Two other shallow crustal earthquake events occurred in 2002 and 2004, and are also categorized as earthquakes at stable continental region, whereas the other remaining representative earthquakes are categorized as subduction earthquakes. For the earthquakes which occurred under subduction activity, the 2012 and 2016 events occurred in the intraface zone (focal depth $>50 \mathrm{~km}$ ), whereas the others occurred in the interface zone (focal depth $<50 \mathrm{~km}$ ). By using all the information provided in Figures 1 and 2 and Tables 1 and 2, attenuation model analysis is performed. Furthermore, among these earthquakes, the most destructive earthquake from the 2000-2016 period is determined. This earthquake is defined as the controlling earthquake, considered to be that which had the most significant impact.

Table 2 Maximum PGA of the representative earthquakes for the investigated zones

\begin{tabular}{|c|c|c|c|c|c|c|c|}
\hline \multirow[t]{2}{*}{ Year } & \multirow[t]{2}{*}{$\mathrm{M}_{\mathrm{w}}$} & \multirow{2}{*}{$\begin{array}{l}\text { Earthquake } \\
\text { Mechanism }\end{array}$} & \multirow[t]{2}{*}{ Type } & \multicolumn{3}{|c|}{$\begin{array}{l}\text { PGA at the Investigated Points } \\
(\mathrm{g})\end{array}$} & \multirow[t]{2}{*}{ Attenuation Model } \\
\hline & & & & SPT-1 & SPT-2 & SPT-3 & \\
\hline 2000 & 7.9 & Subduction & Interplate & 0.1553 & 0.1586 & 0.1607 & Atkinson-Boore (2003) \\
\hline 2001 & 7.2 & Subduction & Interplate & 0.1214 & 0.1232 & 0.1239 & Shoustari et al. (2016) \\
\hline 2002 & 5.7 & Shallow Crustal & Stable Continent & 0.0123 & 0.0122 & 0.0122 & Dahle et al. (1995) \\
\hline 2003 & 5.7 & Subduction & Interplate & 0.0296 & 0.0303 & 0.0308 & Shoustari et al. (2016) \\
\hline 2004 & 7.1 & Shallow Crustal & Stable Continent & 0.0155 & 0.0155 & 0.0155 & Dahle et al. (1995) \\
\hline 2005 & 6.2 & Subduction & Interplate & 0.0184 & 0.0183 & 0.0185 & Shoustari et al. (2016) \\
\hline 2006 & 5.8 & Subduction & Interplate & 0.0407 & 0.0416 & 0.0428 & Shoustari et al. (2016) \\
\hline 2007 & 8.6 & Subduction & Interplate & 0.2121 & 0.2119 & 0.2110 & Idini et al. (2017) \\
\hline 2008 & 6.6 & Subduction & Interplate & 0.0517 & 0.0509 & 0.0501 & Shoustari et al. (2016) \\
\hline 2009 & 6.7 & Shallow Crustal & Active Tectonic & 0.0075 & 0.0155 & 0.0151 & Chiou \& Youngs (2014) \\
\hline 2010 & 4.4 & Subduction & Interplate & 0.0020 & 0.0019 & 0.0019 & Shoustari et al. (2016) \\
\hline 2011 & 5.3 & Subduction & Interplate & 0.0897 & 0.0885 & 0.0870 & Shoustari et al. (2016) \\
\hline 2012 & 5.2 & Subduction & Intraplate & 0.0331 & 0.0331 & 0.0329 & Shoustari et al. (2016) \\
\hline 2013 & 4.2 & Shallow Crustal & Active Tectonic & 0.0053 & 0.0053 & 0.0052 & Abrahamson et al. (2014) \\
\hline 2014 & 3.9 & Subduction & Interplate & 0.0111 & 0.0116 & 0.0118 & Shoustari et al. (2016) \\
\hline 2015 & 4.8 & Subduction & Interplate & 0.0293 & 0.0289 & 0.0283 & Shoustari et al. (2016) \\
\hline 2016 & 5.8 & Subduction & Intraplate & 0.0626 & 0.0626 & 0.1042 & Shoustari et al. (2016) \\
\hline \multicolumn{4}{|c|}{$\begin{array}{l}\text { Maximum PGA }\left(\text { PGA }_{\max }\right) \text { of all earthquakes over } 17 \\
\text { years }\end{array}$} & 0.2121 & 0.2119 & 0.2110 & "Controlling earthquake" \\
\hline
\end{tabular}

Tables 2 and 3 show the PGA of the attenuation model analysis of the investigated sites (SPT-1 to SPT-3) and the scale of MMI caused by the representative earthquakes. In the study, all the attenuation models from the relevant sources are used to calculate PGA. Furthermore, from the calculation results, only the highest value is considered for the next step of the analysis, i.e. selecting the controlling earthquake, as presented in Table 2. In this table, the maximum value of PGA on each site and the attenuation model resulting from the maximum PGA between all the relevant models are presented. Based on Table 2, two big earthquakes resulted in the highest impact on the site. The earthquakes occurred in 2000, a $7.9 \mathrm{M}_{\mathrm{w}}$ earthquake with a PGA average of $0.158 \mathrm{~g}$, and in 2007 , the $8.6 \mathrm{M}_{\mathrm{w}}$ earthquake with a PGA average of $0.217 \mathrm{~g}$; both were triggered by subduction zone activity. In Table 3, the MMI earthquake scale is presented. This scale is derived from Tjokrodimuljo's (2000) method, by which it can be estimated by $\log (\mathrm{PGA})=($ MMI scale/3). The MMI scales for the earthquakes are VIII and IX respectively. Both earthquakes had the potential to result in very serious damage, as reflected by very high levels of MMI. A detailed description of the MMI scale can be found in Wood and Neumann (1931). In line with the results, the 2007 earthquake was selected as the controlling earthquake event in the study area. 
Table 3 Maximum MMI of the representative earthquakes for the investigated zones

\begin{tabular}{cccccccc}
\hline \multirow{2}{*}{ Year } & $\begin{array}{c}\text { Magnitude } \\
\left(\mathrm{M}_{\mathrm{w}}\right)\end{array}$ & \multicolumn{2}{c}{ PGA at the Investigated Points $(\mathrm{g})$} & \multicolumn{2}{c}{ Modified Mercalli Intensity (MMI) } \\
\cline { 3 - 7 } & SPT-1 & SPT-2 & SPT-3 & SPT-1 & SPT-2 & SPT-3 \\
\hline 2000 & 7.9 & 0.1553 & 0.1586 & 0.1607 & VIII & VIII & VIII \\
2001 & 7.2 & 0.1214 & 0.1232 & 0.1239 & VIII & VIII & VIII \\
2002 & 5.7 & 0.0123 & 0.0122 & 0.0122 & V & V & V \\
2003 & 5.7 & 0.0296 & 0.0303 & 0.0308 & VI & VI & VI \\
2004 & 7.1 & 0.0155 & 0.0155 & 0.0155 & V & V & V \\
2005 & 6.2 & 0.0184 & 0.0183 & 0.0185 & V & V & V \\
2006 & 5.8 & 0.0407 & 0.0416 & 0.0428 & VI & VI & VI \\
2007 & 8.6 & 0.2121 & 0.2119 & 0.2110 & IX & IX & IX \\
2008 & 6.6 & 0.0517 & 0.0509 & 0.0501 & VII & VII & VII \\
2009 & 6.7 & 0.0075 & 0.0155 & 0.0151 & IV & IV & IV \\
2010 & 4.4 & 0.0020 & 0.0019 & 0.0019 & II & II & II \\
2011 & 5.3 & 0.0897 & 0.0885 & 0.0870 & VII & VII & VII \\
2012 & 5.2 & 0.0331 & 0.0331 & 0.0329 & VI & VI & VI \\
2013 & 4.2 & 0.0053 & 0.0053 & 0.0052 & IV & IV & IV \\
2014 & 3.9 & 0.0111 & 0.0116 & 0.0118 & V & V & V \\
2015 & 4.8 & 0.0293 & 0.0289 & 0.0283 & VI & VI & VI \\
2016 & 5.8 & 0.0626 & 0.0626 & 0.1042 & VII & VII & VII \\
\hline
\end{tabular}

\subsection{Input Motions}

To reduce the uncertainty of the observed locations, determination of ground motions based on those of the different sources was conducted. Since this study aims to make seismic response analysis and compare this to the Indonesian Seismic Design Code (SNI 03-1726-2012), the regulations in the design code need to be considered, especially the minimum number of analysed ground motions (at least five). In the study, the five source ground motions used were:

1) Loma Prieta Earthquake, 18 October 1989, 090 CDMG Station 47381

2) Imperial Valley Earthquake, 15 October 1979, USGS Station 5115

3) Kobe Earthquake, 16 January 1995, Kakogawa CUE90 Station

4) Northridge Earthquake, 17 January 1994, 090 CDMG Station 24278

5) Chichi Earthquake, 20 September 1999, TCU045 Station

Furthermore, the source ground motions were scaled corresponding to the maximum PGA of each investigated site (SPT-1, SPT-2 and SPT-3), obtained from the attenuation model analysis. Examples of the scaled source ground motions are shown in Figure 3.

\subsection{One-dimensional Seismic Response Analysis}

\subsubsection{Soil behavior under dynamic load}

One-dimensional non-linear seismic response analysis based on the non-linear finite element approach was conducted. In the model, soil non-linearity simulated by incremental plasticity was performed to observe deformation and damping, as well as excess pore water pressure, if liquefaction is also considered. This method was developed by Lu et al. (2006), and is based on the effective stress concept (Ishihara et al., 1975; Parra, 1996; Yang, 2000) combined with the multi-yield surface framework proposed by Prevost (1985). In this method, the incremental stiffness is evaluated, with emphasis placed on controlling the permanent strain deformation. An illustration of soil behavior in the model is presented in Figure 4.

\subsubsection{Soil parameters}

The main soil parameters used in the non-linear seismic response analysis included shear wave velocity $\left(\mathrm{V}_{\mathrm{S}}\right)$, mass density $(\rho)$, friction angle $(\phi)$, cohesion (c), Poisson's ratio (U), effective mean confinement pressure $\left(\mathrm{p}^{\prime}\right)$, coefficient of lateral earth pressure $\left(\mathrm{K}_{\mathrm{o}}\right)$, peak shear strain $(\gamma)$, and number of yield surfaces, amongst others. The parameters related to soil properties and field measurement were determined from laboratory tests and site investigation. For other specific parameters, assumptions were made. The list of parameters used in this study for each layer is summarized in Table 4. 

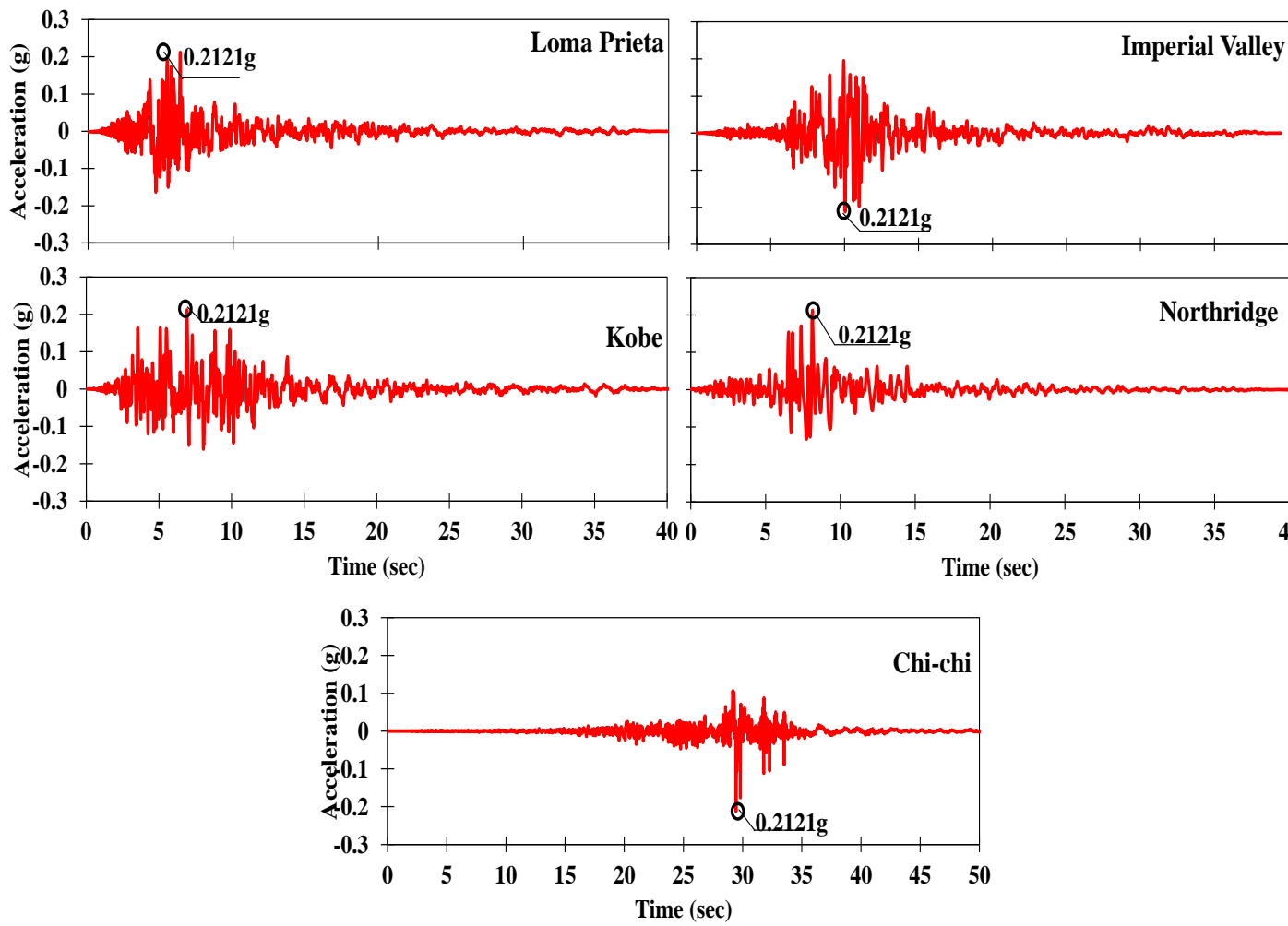

Figure 3 Examples of the scaled ground motions for SPT-1
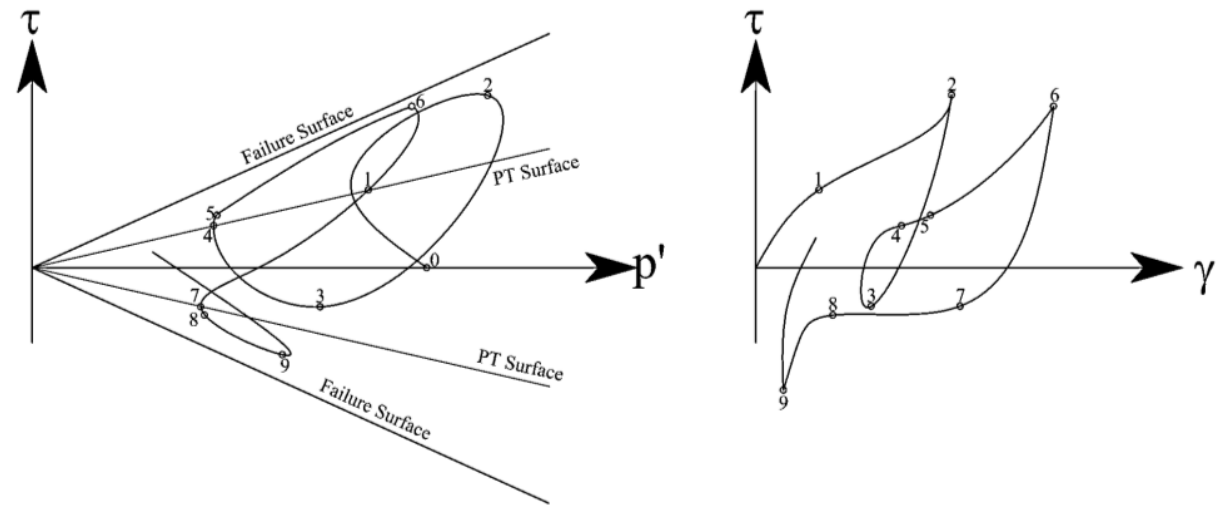

(a)
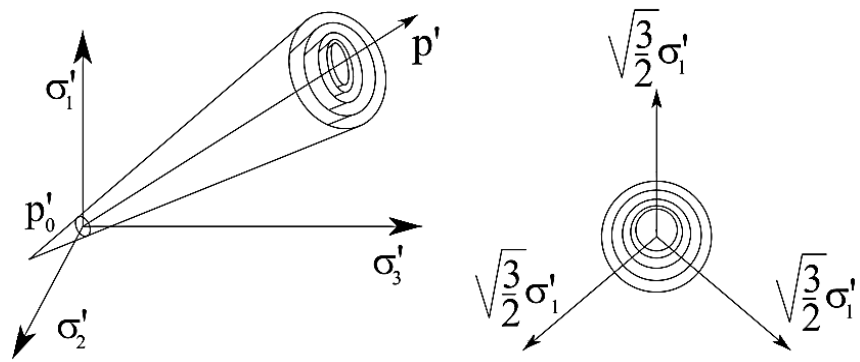

(b)

Figure 4 Soil behavior under dynamic load: (a) effective stress path (adapted from Lu et al., 2006); (b) multi-yield surface mechanism (adapted from Lu et al., 2006)

The material properties (Table 4) of each layer were determined based on either undisturbed or disturbed sampling tests from the soil samples taken from boring test. Brief explanations of the 
material properties are given below (a detailed explanation of the soil parameters can be found in Lu et al., 2006).

1) $\rho$ is soil density, FC is soil fines content, $\mathrm{c}$ is soil cohesion, $\phi$ is the internal friction angle of the soil, and $\mathrm{h}$ is layer thickness

2) $V_{S}$ is average shear wave velocity for the soil layer

3) $K_{o}$ is the coefficient of lateral earth pressure at rest, and $P_{\text {ref }}$ is reference mean effective confinement

4) $\gamma_{\max }$ is peak shear strain, $v$ is Poisson's ratio, $G$ is shear modulus, and $K$ is bulk modulus.

5) The yield surface number is assumed to be 20 , which is based on the recommendation provided in Lu et al. (2006).

In this study, since the depth of investigation is only $30 \mathrm{~m}$ below the ground surface, interpolation of shear wave velocity to the surface of the engineering bedrock is performed. As a result, the assumption of the material for the depth of $30 \mathrm{~m}$ to the engineering bedrock surface needs to be adjusted. In the analysis, at the bottom of the borehole, $\mathrm{V}_{\mathrm{S}}$ is assumed to be 760 $\mathrm{m} / \mathrm{s}$, which means it is categorized as a soft rock material. A list of the material assumptions for the interpolated depth is also presented in Table 4.

Table 4 Input parameters used in the simulation

\begin{tabular}{|c|c|c|c|c|c|c|c|c|c|c|c|c|c|c|}
\hline SPT & Layer & Soil Type & $\begin{array}{c}h \\
(\mathrm{~m})\end{array}$ & $\begin{array}{c}\rho \\
(\mathrm{kg} / \mathrm{m} 3)\end{array}$ & $\begin{array}{c}V_{S} \\
(\mathrm{~m} / \mathrm{s})\end{array}$ & $\begin{array}{c}P_{r e f} \\
(\mathrm{kPa})\end{array}$ & $K_{o}$ & $\begin{array}{c}c \\
(\mathrm{kPa})\end{array}$ & $\begin{array}{c}\phi \\
\left(^{\circ}\right)\end{array}$ & $\begin{array}{l}\gamma_{\max } \\
(\%)\end{array}$ & $v$ & $\begin{array}{l}\mathrm{FC} \\
(\%)\end{array}$ & $G(\mathrm{kPa})$ & $\begin{array}{c}K \\
(\mathrm{kPa})\end{array}$ \\
\hline \multirow{4}{*}{1} & Layer 1 & SP & 1.5 & 1760 & 116 & 100 & 0.515 & 2 & 29 & 5 & 0.4 & 5 & 23842 & 111263 \\
\hline & Layer 2 & SM & 13.5 & 1900 & 281 & 100 & 0.470 & 5 & 32 & 5 & 0.4 & 14 & 149967 & 699844 \\
\hline & Layer 3 & SM & 15 & 2100 & 336 & 100 & 0.470 & 6 & 32 & 5 & 0.4 & 17 & 237067 & 1106311 \\
\hline & Layer 4 & Assumed & 20 & 2200 & 555 & 100 & 0.470 & 6 & 32 & 5 & 0.4 & 17 & 677655 & 3162390 \\
\hline \multirow{6}{*}{2} & Layer 1 & $\mathrm{SP}$ & 1.5 & 1750 & 97 & 100 & 0.531 & 2 & 28 & 5 & 0.4 & 4 & 16389 & 76483 \\
\hline & Layer 2 & SM & 15 & 1910 & 265 & 100 & 0.500 & 5 & 30 & 5 & 0.4 & 18 & 134005 & 625357 \\
\hline & Layer 3 & SW & 3 & 2120 & 319 & 100 & 0.485 & 1 & 31 & 5 & 0.4 & 5 & 215437 & 1005374 \\
\hline & Layer 4 & SM & 3 & 1900 & 292 & 100 & 0.515 & 7 & 29 & 5 & 0.4 & 15 & 161844 & 755272 \\
\hline & Layer 5 & $\mathrm{SC}$ & 7.5 & 2100 & 339 & 100 & 0.470 & 10 & 32 & 5 & 0.4 & 20 & 241691 & 1127893 \\
\hline & Layer 6 & Assumed & 20 & 2200 & 553 & 100 & 0.470 & 10 & 32 & 5 & 0.4 & 20 & 672780 & 3139639 \\
\hline \multirow{6}{*}{3} & Layer 1 & $\mathrm{SP}$ & 1.5 & 1720 & 102 & 100 & 0.515 & 1 & 29 & 5 & 0.4 & 4 & 18062 & 84291 \\
\hline & Layer 2 & SM & 6 & 1905 & 286 & 100 & 0.500 & 3 & 30 & 5 & 0.4 & 13 & 155767 & 726913 \\
\hline & Layer 3 & SP & 1.5 & 1700 & 127 & 100 & 0.531 & 1 & 28 & 5 & 0.4 & 7 & 27589 & 128751 \\
\hline & Layer 4 & SM & 12 & 1900 & 306 & 100 & 0.485 & 4 & 31 & 5 & 0.4 & 10 & 177671 & 829131 \\
\hline & Layer 5 & $\mathrm{SC}$ & 9 & 2100 & 343 & 100 & 0.470 & 9 & 32 & 5 & 0.4 & 10 & 246930 & 1152339 \\
\hline & Layer 6 & Assumed & 20 & 2200 & 553 & 100 & 0.470 & 9 & 32 & 5 & 0.4 & 10 & 672780 & 3139639 \\
\hline
\end{tabular}

\subsubsection{Modelling criteria}

The modelling criteria for the one-dimensional seismic response analysis are depicted in Figure 5. The input motion is applied at the bottom of the soil profile. To ensure that this motion propagates from the bedrock to the ground surface, information on the sediment thickness needs to be obtained. In this study, the estimation of the sediment thickness of the study area (the engineering bedrock surface) was considered based on the passive (microtremor) measurement provided in Refrizon et al.'s (2013) study, i.e. about $50 \mathrm{~m}$ deep. As the soil profile in this study is only $30 \mathrm{~m}$, the soil profile is linearly interpolated by adjusting the $\mathrm{V}_{\mathrm{S}}$ at $50 \mathrm{~m}$ equal to 760 $\mathrm{m} / \mathrm{s}$ (NEHRP, 1998). The interpolating method applied to adjust the soil profile based on $\mathrm{V}_{\mathrm{S}}$ is presented in Figure 6. In the model, the boundary condition is limited in the vertical direction. However, displacements on both vertical and horizontal directions are allowed. If liquefaction analysis is considered, excess pore water pressure can also be observed. This is because there is no drainage path in the lateral direction. The soil column is underlain by the impermeable elastic half space. To determine mesh size, wavelength analysis is made. For the study, a mesh size of $0.5 \mathrm{~m}$ was selected, as suggested by Pender et al. (2016), Mase et al. (2016), Mase et al. (2018a), and Mase et al. (2018b). 


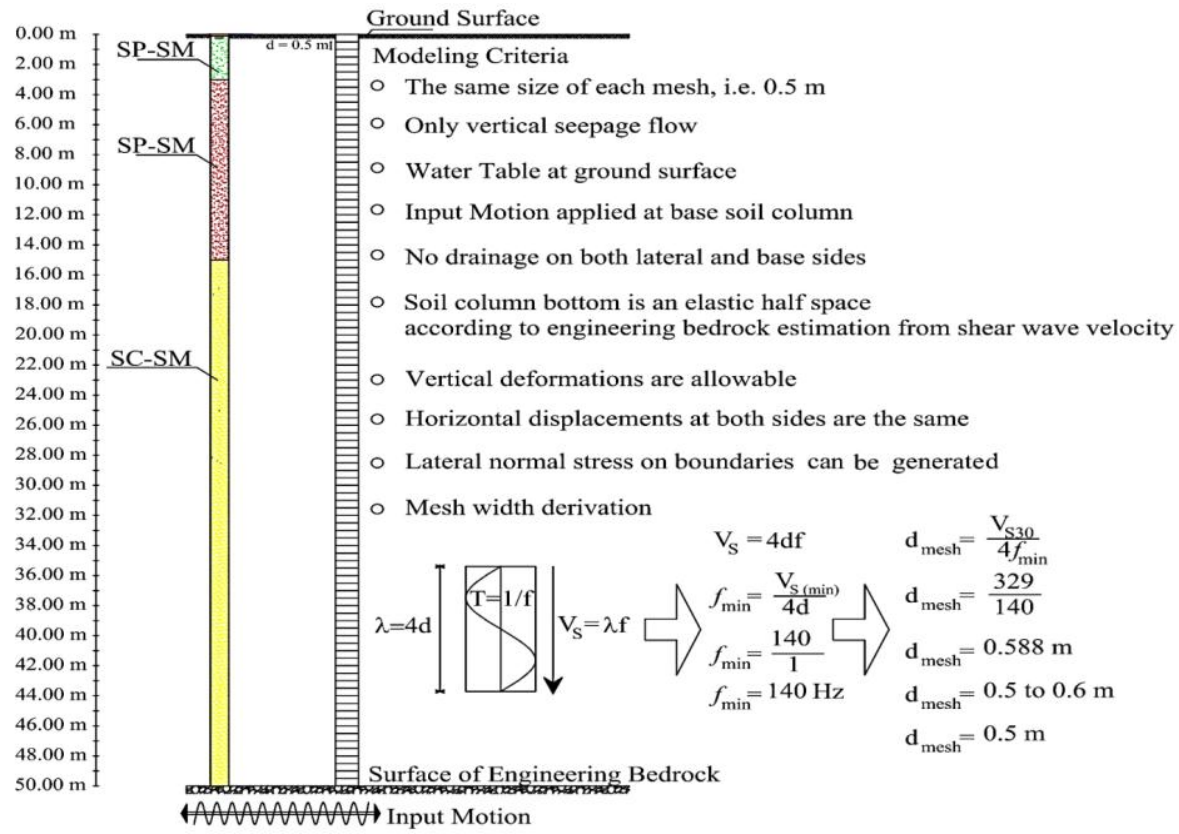

Figure 5 Illustration of one-dimensional seismic analysis (Adapted from Mase et al., 2017)

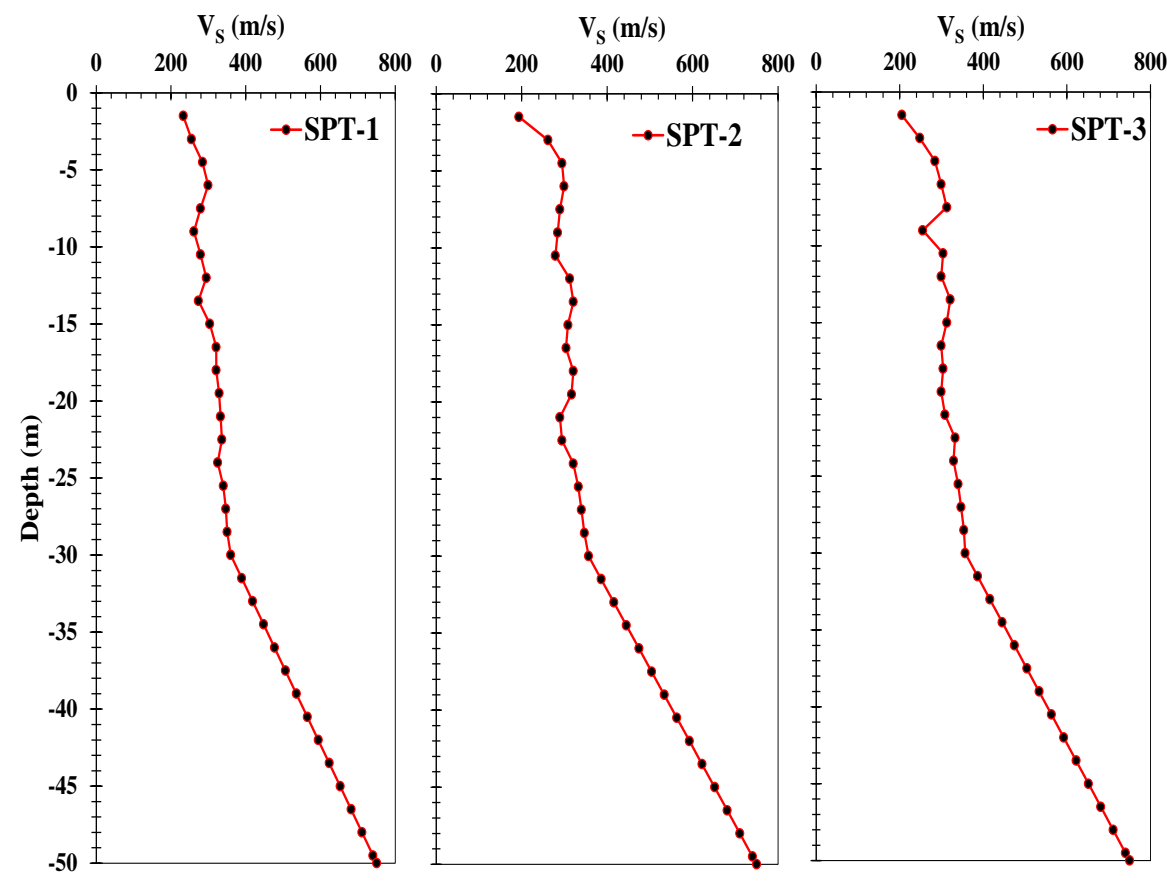

Figure 6 Soil profile interpolation for depths below the investigated layer

\subsection{Spectral Acceleration of SNI 03-1726-2012}

The spectral acceleration of the one-dimensional analysis was compared to the updated spectral acceleration design of SNI 03-1726-2012. This spectral acceleration was also developed based on seismic hazard analysis. The code includes three soil site criteria used in establishing the spectral acceleration for the earthquake load. These are classified as soft soil (SE), medium soil (SD) and stiff soil (SC) spectral accelerations. The soil site type can be predicted based on the value of soil resistance, such as $\left(\mathrm{N}_{1}\right)_{60}$ for the first $30 \mathrm{~m}$ of depth and $\mathrm{V}_{\mathrm{S} 30}$. The designed earthquake of SNI 03-1726-2012 was assigned as the earthquake with a $2 \%$ probability of exceedance in 50 years. The design code specified a return period of 2,475 years. 


\section{RESULTS AND DISCUSSION}

\subsection{Maximum Acceleration Profile and Amplification Factor}

The interpretation of the maximum acceleration $\left(\mathrm{PGA}_{\max }\right)$ profile is presented in Figure $7 . \mathrm{In}$ general, the input motion of each source ground motion experiences amplification on each site. The waves almost constantly propagate from a depth of $50 \mathrm{~m}$ to $35 \mathrm{~m}$ and start to amplify at 35 $\mathrm{m}$ up to ground level. Since linearization is applied at depths below $30 \mathrm{~m}$, soil resistance increases with depth. This assumption does not seem to influence the wave propagation significantly. Moreover, at a depth of $30 \mathrm{~m}$ the sub-soil is dominated by dense sand, which may provide almost similar soil resistance to the assumed soil type at depths of 30 to $50 \mathrm{~m}$. However, from a depth of $30 \mathrm{~m}$ to the ground surface, medium and loose sands dominate the sub-soils. The low resistance of sand, especially loose-medium sand, contributes to the amplification of the seismic propagation wave. Generally, the ground motion is amplified by about 1.9 to 2.7 times its initial value (Table 5); the Loma Prieta earthquake generated the highest amplification on each site, and the Chichi earthquake generated the lowest amplification.

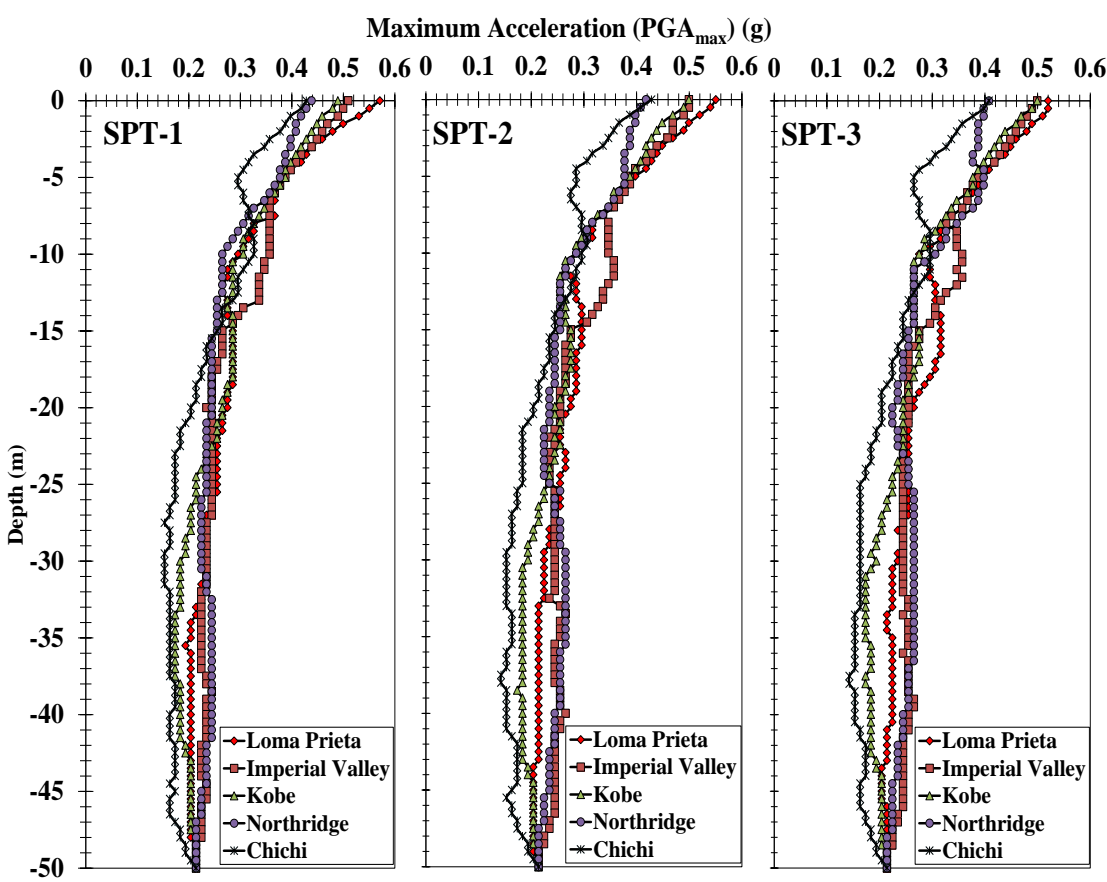

Figure 7 Maximum acceleration $\left(\mathrm{PGA}_{\max }\right)$ profile resulting from the five source ground motions

Table 5 Amplification factor of each investigated site

\begin{tabular}{lcclc}
\hline SPT-1 & & & & \\
\hline Loma Prieta & Imperial Valley & Kobe & Northridge & Chichi \\
2.678 & 2.304 & 2.392 & 2.044 & 2.033 \\
\hline SPT-2 & & & & \\
\hline Loma Prieta & Imperial Valley & Kobe & Northridge & Chichi \\
2.585 & 2.357 & 2.374 & 1.960 & 2.007 \\
\hline SPT-3 & & & & \\
\hline Loma Prieta & Imperial Valley & Kobe & Northridge & Chichi \\
2.482 & 2.356 & 2.366 & 1.930 & 1.944 \\
\hline
\end{tabular}

\subsection{Spectral Acceleration Comparison}

Comparison of the spectral acceleration resulting from the seismic response and the designed spectral acceleration at the ground surface is presented in Figure 8. In general, the spectral 
acceleration of seismic response analysis exceeds the spectral acceleration design for all site classes, especially on short period (Period $\left(T_{n}\right) \leq 0.2 \mathrm{~s}$ ). In Bengkulu City, two story buildings are commonly found. The natural period of a building can be simply estimated by $T_{n}=0.1 \mathrm{n}$, where $n$ is the number of stories. Therefore, for a two-story building, $T_{n}$ is $0.2 \mathrm{~s}$.

In general, the results also show that for 2 to 7 story buildings ( $T_{n}$ of 0.2 to $1 \mathrm{~s}$ ), the spectral acceleration design is exceeded by the spectral acceleration of the seismic analysis for all soil sites. For long periods $\left(T_{n} \geq 1\right)$, the designed spectral acceleration of all the sites is still sufficient to cover that of the seismic analysis. However, for the natural period of low to medium-rise buildings, this is a warning that Bengkulu, as developing city, may in the future construct many buildings with at least 5 to 7 stories, especially in those investigated locations where the social economy of the city is centralized. Based on this study, the earthquake aspect should be considered in building design in Bengkulu City.
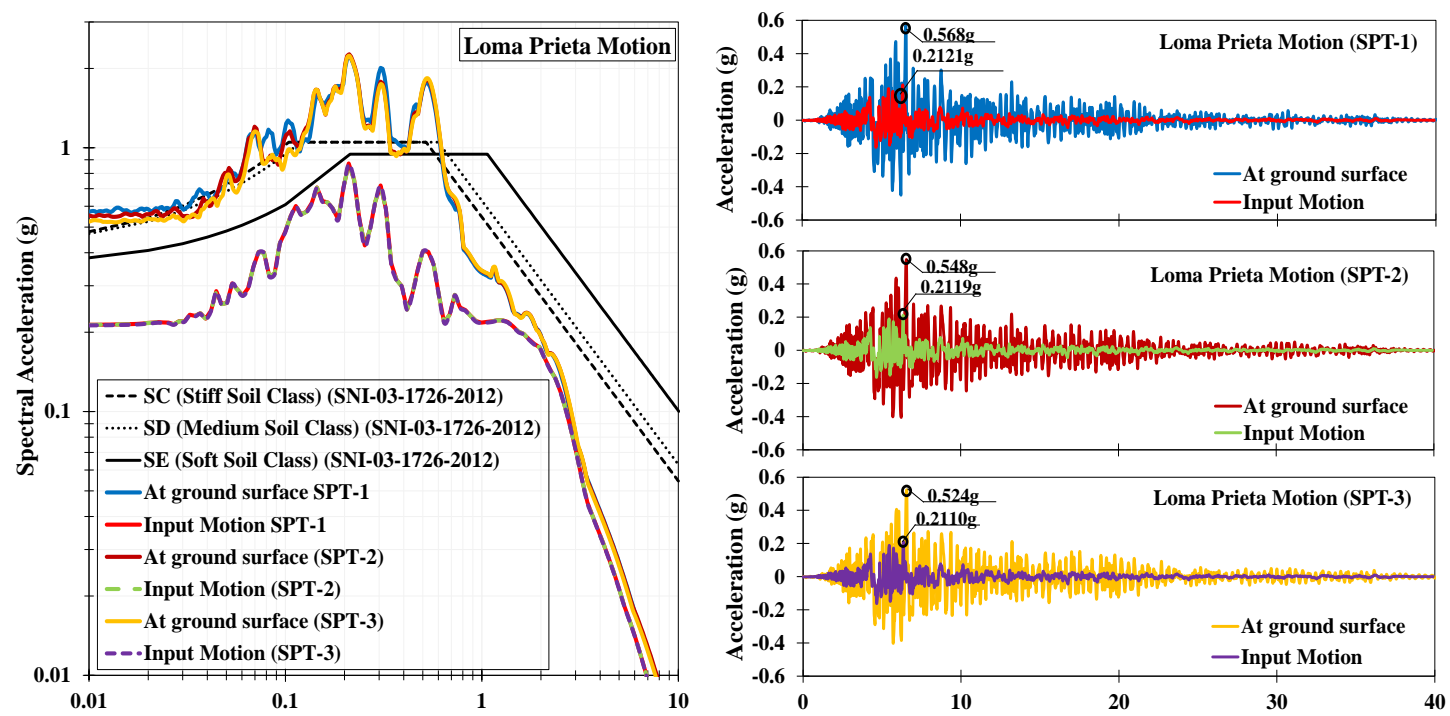

(a)
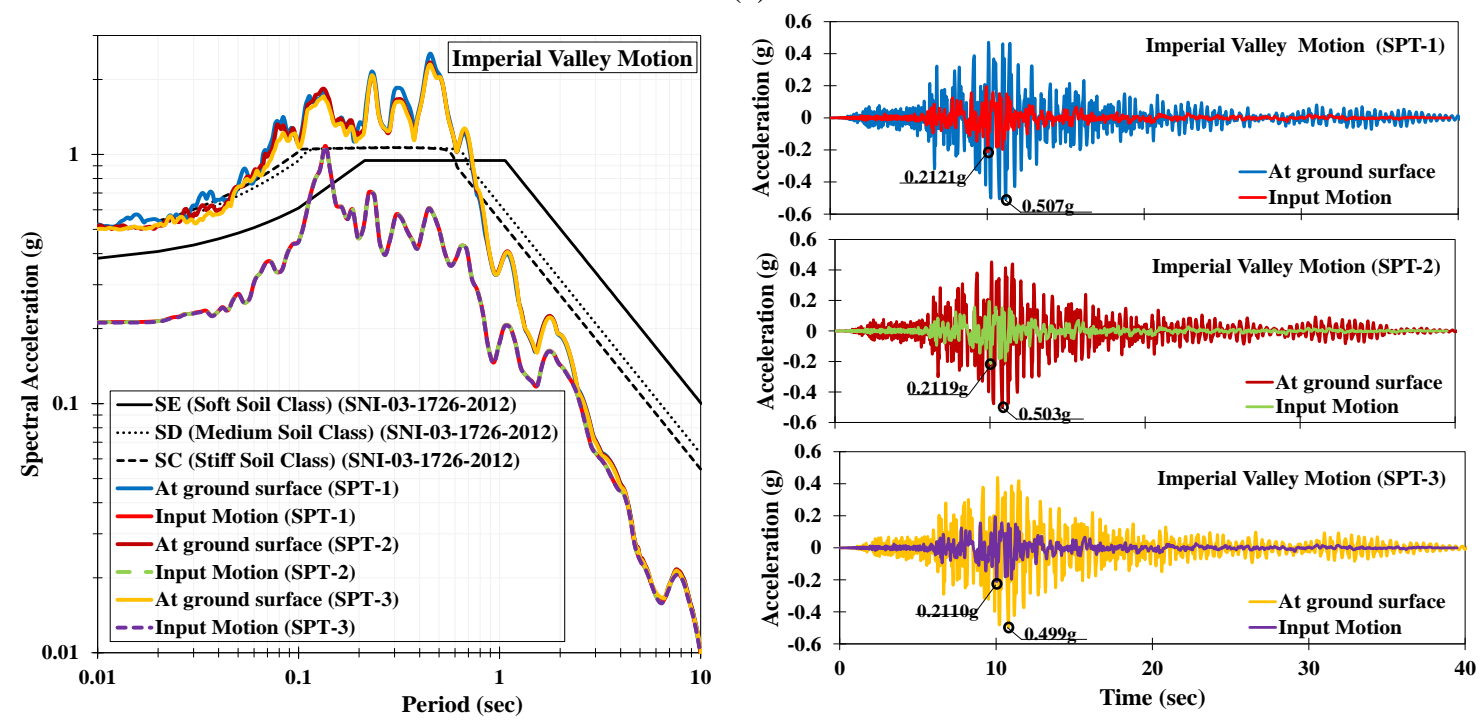

(b) 

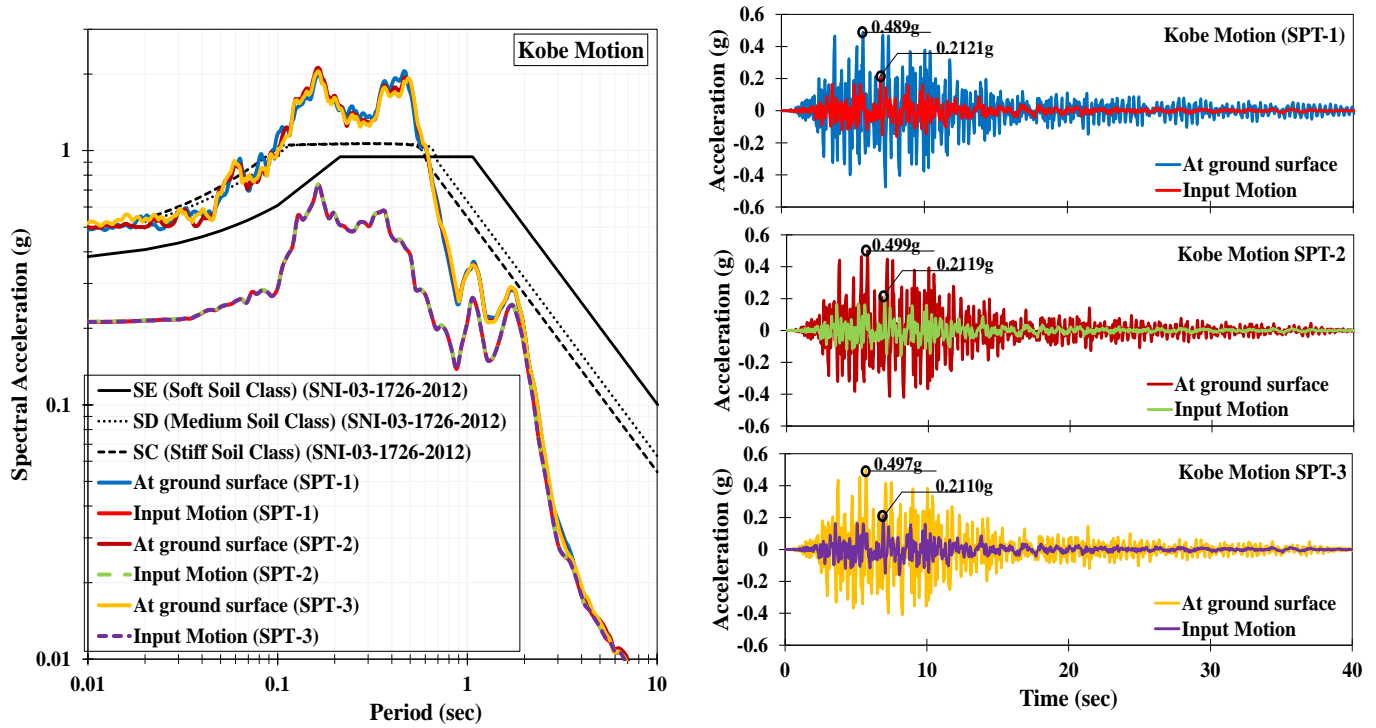

(c)
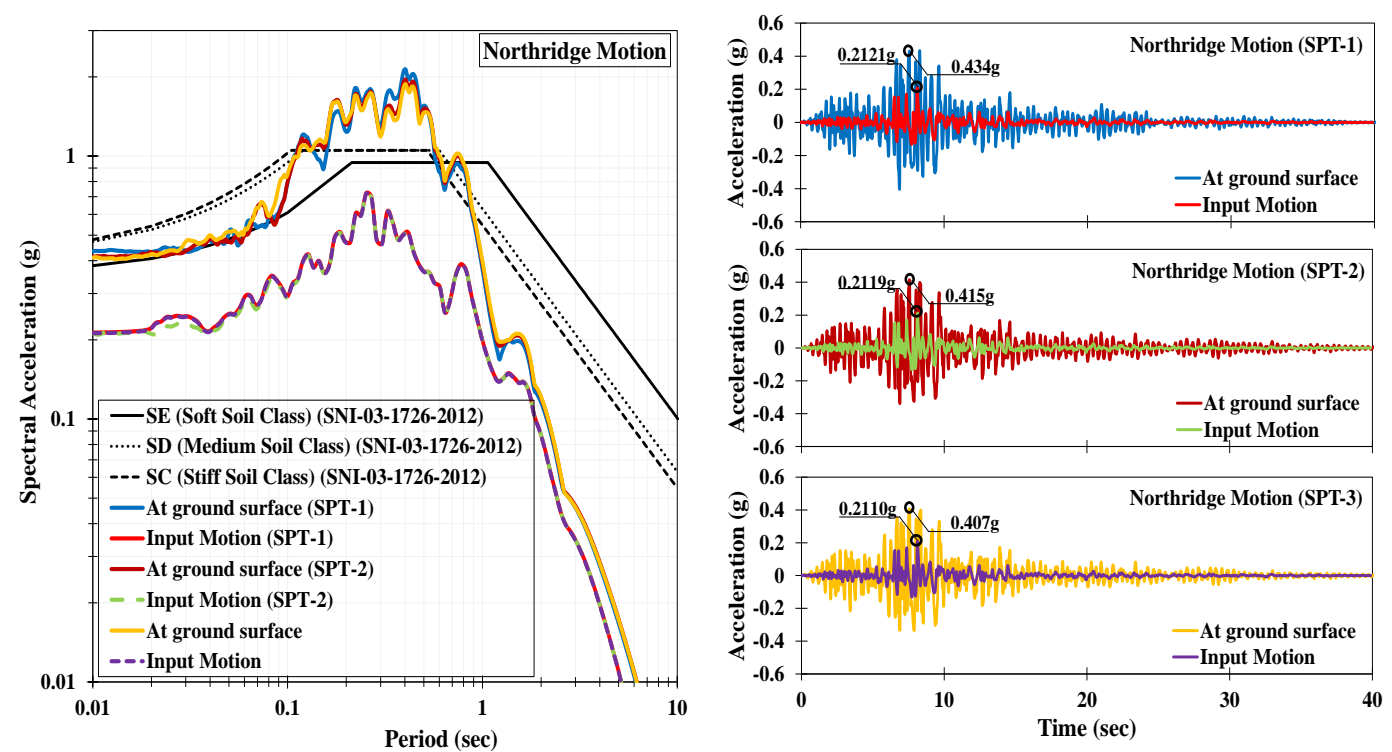

(d)
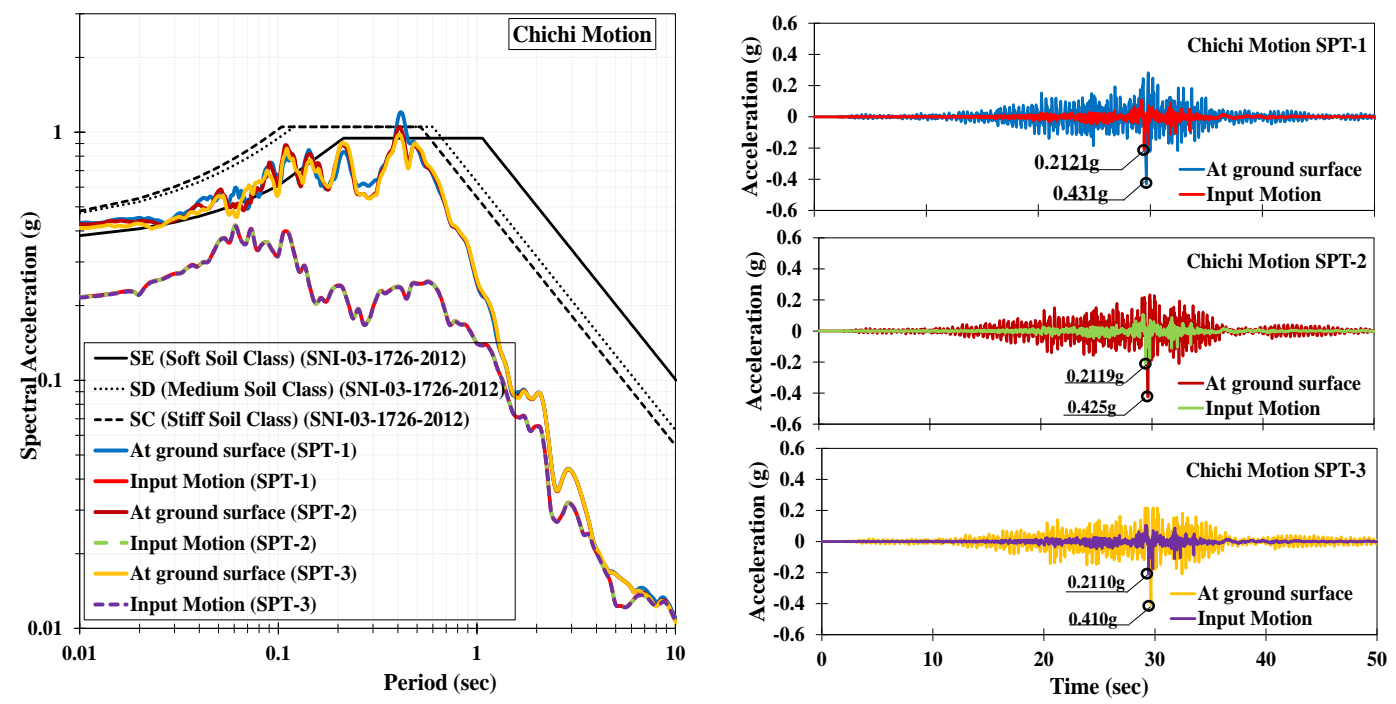

(e)

Figure 8 Spectral acceleration comparison: (a) Loma Prieta motion (b) Imperial Valley motion (c) Kobe motion (d) Northridge motion (e) Chichi motion 
From the results, it can be concluded that the designed spectral acceleration released by SNI 031726-2012 is still able to cover that of the controlling earthquake, especially for long periods. However, buildings with $T_{n} \geq 1 \mathrm{~s}$ are still rare in Bengkulu City. This leads to the recommendation to conduct seismic response analysis before performing the structural analysis for building design in Bengkulu City, especially when designing 2 to 7 story buildings. In addition, the local government should be more careful in giving permission to construct buildings in this area, especially those that have not considered the specific earthquake load in the design aspect.

\section{CONCLUSION}

The results show that the designed spectral acceleration is still able to cover the spectral acceleration resulting from the wave propagation of the controlling earthquake. However, for $T_{n}$ $\leq 0.2 \mathrm{~s}, 0.2 \mathrm{~s} \leq T_{n} \leq 0.7 \mathrm{~s}$, the designed spectral acceleration for three site classes (soft soil, medium soil and stiff soil) are exceeded by the spectral acceleration of the seismic response analysis. In addition, the great case needs to be taken when designing earthquake loads for the buildings. This study also brings a recommendation to study liquefaction in the investigated sites, since the sandy soils are generally found in the investigated sites. The numerical analysis as performed by Mase et al. (2017a) and the experimental study as performed by Mase (2017b) can be performed in the future.

\section{ACKNOWLEDGEMENT}

The author would be grateful for the earthquake data from National Agency for Meteorology, Climatology and Geophysics, or BMKG, which are used in this study.

\section{REFERENCES}

Abrahamson, N.A., Silva W.J., Kamai, R., 2014. Summary of the ASK14 Ground Motion Relation for Active Crustal Regions. Earthquake Spectra, Volume 30(3), pp. 1025-1055.

Atkinson, G.M., Boore, D.M., 2003. Empirical Ground-Motion Relations for Subduction Zone Earthquakes and Their Application to Cascadia and Other Regions. Bulletin of the Seismological Society of America, Volume 93(4), pp.1703-1729

Badan Meteorologi Kimatologi dan Geofisika (BMKG), 2017. Earthquake Data in 2000-2009. BMKG. Available online at http://www.bmkg.go.id [in Bahasa]

Boore, D.M., Stewart, J.P., Seyhan, E., Atkinson, G.M., 2014. NGA-West 2 Equations for Predicting PGA, PGV, and 5\%-Damped PSA for Shallow Crustal Earthquakes. Earthquake Spectra, Volume 30(3), pp. 1057-1085

Campbell, K.W., Bozorgnia, Y., 2014. NGA-West2 Ground Motion Model for the Average Horizontal Components of PGA, PGV, and 5\% Damped Linear Acceleration Response Spectra. Earthquake Spectra, Volume 30(3), pp. 1087-1115

Chiou, B,S-J., Youngs, R.R., 2014. Update of the Chiou and Youngs NGA Model for the Average Horizontal Component of Peak Ground Motion and Response Spectra. Earthquake Spectra, Volume 30(3), pp. 1117-1153

Dahle, A., Climent, A., Taylor, W., Bungum, H., Santos, P., Ciudad Real, M., Linholm, C., Strauch, W., Segura, F., 1995. New Spectral Strong Motion Attenuation Models for Central America. In: Proceedings of the Fifth International Conference on Seismic Zonation, Nice, 17-19 October, France

Google Earth, 2017. Bengkulu Province Region. Available online at http: www.google.co.id

Hwang, H., Huo, J.R., 1997. Attenuation Relations of Ground Motion for Rock and Soil Sites in Eastern United States. Soil Dynamics and Earthquake Engineering, Volume 16(6), pp. $363-372$ 
Idini, B., Rojas, F., Ruiz, S, Pastén, C., 2017. Ground Motion Prediction Equations for the Chilean Subduction Zone. Bulletin of Earthquake Engineering, Volume 15(5), pp. 18531880

Ishihara, K., Tatsuoka, F., Yasuda, S., 1975. Undrained Deformation and Liquefaction of Sand under Cyclic Stresses. Soils and Foundation, Volume 15(1), pp. 29-44

Kanata, B., Zubaidah, T., Ramadhani, C., Irmawati, B., 2014. Changes of the Geomagnetic Signal Linked to Tohoku Earthquake on March $11^{\text {th }}$ 2011. International Journal of Technology, Volume 5(3), pp. 251-258

Kataoka, S., Satoh, T., Matsumoto, S., Kusakabe, T., 2006. Attenuation Relationships of Ground Motion Intensity using Short Period Level as a Variable. Doboku Gakkai Ronbunshuu A, Volume 62(4), pp. 740-757

Kinasih, I.P., Wiriasto, G.W., Kanata, B., Zubaidah, T., 2014. Lesser Sunda Islands Earthquake Inter-occurrence Times Distribution Modeling. International Journal of Technology, Volume 5(3). pp. 242-250

Lu, J., Elgamal, A., Yang, Z., 2006. Cyclic1D: A Computer Program for Seismic Ground Response, Report No. SSRP-06/05, Department of Structural Engineering, University of California, San Diego, La Jolla, CA, USA

Mase, L.Z., 2010. Analysis of Damage Intensity Based on MMI and Frequency of Earthquake Occurrence in Province of Bengkulu, Bachelor Thesis, University of Bengkulu, Bengkulu, Indonesia [in Bahasa]

Mase L.Z., Tobita, T., Likitlersuang, S., 2016. Liquefaction Potential in Chiang Rai Province, Northern Thailand due to the $6.8 \mathrm{M}_{\mathrm{w}}$ Earthquake on March 24, 2011, In: Proceeding of the 36 conference on earthquake engineering, JSCE, paper No. 0905 (CD ROOM), Kanazawa, 17-18 October, Japan.

Mase, L.Z., Somantri, A.K., 2016. Development of Spectral Response Design for Bengkulu City Based on Deterministic Approach. In: Proceeding of the $20^{\text {th }}$ Annual Meeting of Indonesian Society for Geotechnical Engineering. 15-16 November, Jakarta, Indonesia, pp. $147-152$

Mase L.Z., 2017a. Liquefaction Potential Analysis along Coastal Area of Bengkulu Province due to the $2007 \mathrm{M}_{\mathrm{w}}$ 8.6 Bengkulu Earthquake. Journal of Engineering and Technological Sciences, Volume 4(6), pp. 721-736

Mase, L.Z., 2017b. Shaking Table Test of Soil Liquefaction in Southern Yogyakarta. International Journal of Technology, Volume 8(4), pp. 747-760

Mase L.Z., Tobita, T., Likitlersuang, S., 2017. One-dimensional Analysis of Liquefaction Potential: A Case study in Chiang Rai Province, Northern Thailand. Journal of Japanese Society of Civil Engineers, Ser A1 (Structural Engineering/Earthquake Engineering), Volume 73(4) pp. I_135-I_147

Mase, L. Z., Likitlersuang, S., Tobita, T. 2018a. Non-linear Site Response Analysis of Soil Sites in Northern Thailand during the Mw 6.8 Tarlay Earthquake. Engineering Journal, 22(3), 291-303

Mase, L. Z., Likitlersuang, S., Tobita, T. 2018b. Analysis of Seismic Ground Response Caused During Strong Earthquake in Northern Thailand. Soil Dynamics and Earthquake Engineering, Volume114, pp. 113-126

National Earthquake Hazards Reduction Program (NEHRP), 1998. Recommended provisions for seismic regulation for new buildings and other structures, 1997 Edition, FEMA 302, USA

Parra, E., 1996. Numerical Modelling of Liquefaction and Lateral Ground Deformation Including Cyclic Mobility and Dilation Response in Soil Systems, PhD Thesis, Rensselaer Polytechnic Institute, New York, USA 
Pender, M.J., Orense, R.P., Wotherspoon, L.M., Storie, L.B., 2016. Effect of Permeability on the Cyclic Generation and Dissipation of Pore Pressures in Saturated Gravel Layers. Geothechnique, Volume 66(4), pp. 313-322

Pezeshk, S., Zandieh, A., Tavakoli, B., 2011. Hybrid Empirical Ground-Motion Prediction Equations for Eastern North America using NGA Models and Updated Seismological Parameters. Bulletin of the Seismological Society of America, Volume 101(4), pp.18591870

Prevost, J.H., 1985. A Simple Plasticity Theory for Frictional Cohesionless Soils. International Journal of Soil Dynamics and Earthquake Engineering, Volume 4(1), pp. 9-17

Refrizon, Hadi, A.I., Lestari, K., Octari, T., 2013. Analysis of Peak Ground Acceleration and Seismic Vulnerability in Ratu Agung Bengkulu City, In: Proceeding of Semirata FMIPA UNILA, Lampung, 10-12 May, Indonesia [in Bahasa]

Reiter, L., 1990. Earthquake Hazard Analysis: Issues and Insight, Columbia University Press, New York, USA

Shoushtari, A.V., Adnan, A.B., Zare, M., 2016. On the Selection of Ground-Motion Attenuation Relations for Seismic Hazard Assessment of the Peninsular Malaysia Region due to Distant Sumatran Subduction Intraslab Earthquakes. Soil Dynamics and Earthquake Engineering, Volume 82(1), pp. 123-137

SNI 03-1726-2002, 2002. Standard of Earthquake Resistance Design for Building, Ministry of Public Works, Jakarta, Indonesia [in Bahasa]

SNI 03-1726-2012, 2012. Standard of Earthquake Resistance Design for Building, National Standardization Agency, Jakarta, Indonesia [in Bahasa]

Sukanta, I.N., Prakoso, W.A., Ilyas, T., Irsyam, M., 2015. Development of an Extended Hara Model for $\mathrm{M}_{\mathrm{w}}$ Determination of Moderate-Magnitude Earthquakes. International Journal of Technology, Volume 6(3), pp. 380-387

Tjokrodimuljo, K., 2000. Earthquake Engineering. Department of Civil Engineering, Gadjah Mada University, Yogykarta, Indonesia [in Bahasa]

Toro, G.R., 2002. Modification of the Toro et al. (1997) Attenuation Equations for Large Magnitudes and Short Distances. Technical Report Risk Engineering Inc., pp. 4-1-4-10

Wood H.O., Neumann, F., 1931. Modified Mercalli Intensity of 1931. Bulletin of the Seismological Society of America, Volume 21(4), pp. 277-283

Yang, Z., 2000. Numerical Modelling of Earthquake Site Response Including Dilation and Liquefaction, PhD Dissertation, Columbia University, New York, USA 